\title{
Influence of data sources and processing methods on theoretical river network quality
}

\author{
Francisco J. Peñas*, Felipe Fernández, Milena Calvo, José Barquín and Luis Pedraz \\ Environmental Hydraulics Institute (IH Cantabria). Universidad de Cantabria, Parque Científico y Tecnológico \\ de Cantabria. C/Isabel Torres, 15, 39011, Santander, Spain.
}

*Corresponding author: penasfj@unican.es

Received: $7 / 4 / 2010 \quad$ Accepted: $22 / 3 / 2011$

\begin{abstract}
Influence of data sources and processing methods on theoretical river network quality

Stream ecosystem research and water resource management need to be considered over broad spatial scales. Moreover, the investigation of the spatial configuration and habitat characteristics of streams requires an accurate and precise spatial framework to reflect a catchment's physical reality that can successfully explain observed patterns at smaller scales. In this sense, geographic information systems represent an essential tool to satisfy the needs of researchers and managers. Specifically, theoretical river networks (TRNs) extracted from digital elevation models (DEMs) have become much more common in recent years, as they can provide a suitable spatial network and hierarchical organisation to sort out river ecosystem information from reach to catchment levels. Nevertheless the quality of the extracted TRN depends greatly on the spatial resolution of the DEM and the methodology used in the network extraction processes.

In this study, we compare the quality of 9 TRNs extracted from DEMs with different spatial resolutions ranging from regional $(5 \mathrm{~m})$ to national $(25 \mathrm{~m})$ and global scales $(90 \mathrm{~m})$ using the ArcHydro, Hec-GeoHMS and Netstream software packages. To achieve our goal, we compared (i) the DEM-derived slope; (ii) the spatial accuracy of the TRNs in relation to a control river network; (iii) the structure of the TRNs through analysis of the number of river segments, average river segment length and total river length by stream order, drainage density and the mean upstream slope throughout the TRN; and (iv) the ability of variables derived from TRNs to discriminate among stream types classified according to flow type and substrate composition. We demonstrated that not only DEM spatial resolution but also the DEM data source and raster creation process exert an important influence on terrain characteristics derived from DEMs and TRN properties. Moreover, TRNs extracted with NetStream generally showed better performance than those extracted with ArchHydro and HecGeoHMS. Nevertheless, river network extraction quality, DEM spatial resolution and extraction algorithms exhibit complex relationships due to the large number of interacting factors.
\end{abstract}

Key words: Fluvial ecosystems, spatial hierarchy, Theoretical River Networks, Digital Elevation Models, extraction algorithm.

\section{RESUMEN}

\section{Influencia de las fuentes de datos y los metodos de extracción en la calidad de las redes fluviales teóricas}

La investigación de los ecosistemas acuáticos continentales y la gestión de recursos hídricos necesitan ser considerados a escalas espaciales que abarquen grandes territorios. Así mismo, el estudio de la configuración espacial de los sistemas fluviales y las características del hábitat requieren de un marco espacial preciso con el que explicar los patrones observados a pequeña escala a partir de las características físicas de la cuenca. En este sentido, los sistemas de información geográfica representan una herramienta esencial. Específicamente, la extracción de redes fluviales teóricas (RFT) a partir de modelos digitales de elevación (MDEs) ha sufrido una importante expansión y desarrollo en los últimos años. Las RTF, proporcionan un marco espacial adecuado e integran la estructura jerárquica de los ecosistemas fluviales, de tal modo que pueden englobar información a diferentes escales espaciales, desde el nivel de cuenca al de tramo. Sin embargo, la calidad de las RFTs depende, en gran medida, de la resolución espacial de los MDE y de los métodos utilizados en el proceso de extracción de la red. En este estudio hemos comparado la calidad de 9 RFTs obtenidas a partir de MDEs con diferentes resoluciones espaciales, que van desde la escala regional (5 m), nacional $(25 \mathrm{~m})$ hasta global (90 m) mediante ArcHydro, Hec-GeoHMS y NetStream. 
Para lograr nuestro objetivos hemos comparado (i) las características de la pendiente derivada de los MDEs, (ii) la precisión espacial de las RFT en relación a una red fluvial control, (iii) la estructura de los RTFs mediante el análisis del número de segmentos, la longitud media y total de los segmentos de cada orden fluvial, la densidad de drenaje y la pendiente media de la cuenca a lo largo de la RFT y (iv) la capacidad de variables físicas derivadas de las RFT para discriminar entre tipos de ríos clasificados con base en el tipo de flujo y la composición del sustrato.

Los resultados obtenidos han demostrado que la calidad de las características físicas derivadas del MDE y las propiedades de las RFTs no están determinadas únicamente por la resolución espacial del MDE, sino que el tipo de dato del que provenga el MDE y el proceso de generación del mismo ejercen una gran influencia. Además, NetStream ha generado, por lo general, unas RTFs más precisas que ArcHydro y HecGeoHMS. Sin embargo, la interacción de un gran número de factores durante el proceso de generación de redes hace que las relaciones entre la calidad de las mismas, la resolución espacial de los MDE y los algoritmos utilizados sean complejas.

Palabras clave: Ecosistemas fluviales, jerarquía espacial, Red Fluvial Teórica, Modelos Digitales de Elevación, algoritmo de extracción.

\section{INTRODUCTION}

Scientists and water managers develop studies and management practices over broad spatial extents (Clarke \& Burnett, 2003; Clarke et al., 2008) that range from single catchments of several square kilometres to complete regions, countries or continents. Moreover, the multi-scale spatial hierarchy of fluvial ecosystems (Frissell et al., 1986) needs to be unravelled through investigation of large-scale landforms and catchment characteristics, which will allow us to predict and link smaller-scale morphological and physical habitat attributes with their formative processes at multiple scales (Wohl \& Merritt, 2005; Flores et al., 2006). Thus, basic geospatial information about stream network configuration and related catchment attributes may attract great interest in water monitoring and modelling (Montgomery et al., 1995; Colombo et al., 2007). These parameters determine many ecosystem processes and functions, including those associated with hydrology (Wu et al., 2008; Strager et al., 2009), geomorphology (Montgomery \& Buffington, 1998; Benda et al., 2004; Flores et al., 2006) and water characteristics (Strayer et al., 2003) and influence significantly the biological communities (Lunetta et al., 1997; Burnett et al., 2003). Once these processes and relationships are understood, geographic information systems (GIS) may represent an essential tool for the integration of environmental information at different spatial scales and provide important support in water resource management (Benda et al., 2007).

Two main spatial data models are available to address geographic information: the vector data model and the raster data model. The first represents discrete entity-defined point, line or polygon units, while the second approach provides tessellations of continuous fields to form geographical representations (Burrough \& McDonell, 1998). These characteristics make the vector data model very attractive for representing discrete features accurately, although the availability of vector data are scarce at large scales, incomplete in many cases and can contain important topological errors. Although the raster data model can also include false data and errors, its simplicity, computational efficiency and availability at different resolutions seem to make this approach a better choice for calculating continuous variations of different attributes over space.

Among digital elevation models (DEM), the availability and quality of DEMs representing a continuous elevation field through a raster or grid structure are increasing rapidly (Nelson et al., 2009). In a raster data model, the representation of the variation of an attribute for a given purpose, in this case altitude, is determined by its resolution (Burrough \& McDonell, 1998). There are currently datasets that offer different levels of spatial resolution, from high spatial resolution sources, such as light detection and ranging (LIDAR) data, to global datasets, such as Shut- 
tle Radar Topography Mission (SRTM) data (Li \& Wong, 2010). Other concerns regarding data quality are associated with the techniques and protocols followed to develop DEMs from raw data. There are generally three sources of DEMs: (i) ground survey techniques, (ii) existing topographic maps and (iii) remote sensing (Nelson et al., 2009). For example, the advance spaceborne thermal emission and reflection radiometer sensor (ASTER) provides a better spatial resolution than the SRTM, although both techniques provide much lower resolution than topographic maps $(5 \mathrm{~m}$ or $25 \mathrm{~m}$ ) or laser techniques (e.g., LIDAR). Moreover, the SRTM model is one of the most used DEMs, being employed for purposes ranging from analysis of the earth's surface to modelling applications (Tarolli et al., 2009). However, it presents three main disadvantages: (i) its elevation data include information from dense vegetation and built-up areas, and in this sense, it is not a bare-earth model; (ii) at land-water interfaces, the interpherometric process can produce areas without data; and (iii) in mountain or desert areas, problems can occur due to foreshortening and shadowing (Nelson et al., 2009). In contrast, the main disadvantage of the ASTER sensor is its passive nature, which generate areas with missing data due to cloud cover (Nelson et al., 2009). However, these missing data can be filled with new cloud-free ASTER scenes.

Few studies have evaluated the quality of different DEMs (but see Nelson et al., 2009) and the effect that DEM spatial resolution has on the process of river network extraction (e.g., Wang \& Yin, 1998; McMaster, 2002; Clarke \& Burnett, 2003).The selection of DEMs for hydrological and geomorphological studies is normally focused on DEMs with the highest resolution available, dismissing DEMs with lower resolutions. This may not always be the most appropriate approach because the modelling processes require sophisticated hardware to be run and may not extract river networks with the best spatial accuracy or spatial structure (Wang \& Yin, 1998; Li \& Wong, 2010). Moreover, the availability of DEM data for some areas might be very limited in some cases.

DEMs not only provide a description of threedimensional surfaces but also set the founda- tion for deriving other parameters, such as slope, curvature, slope profile and catchment area, that have been widely used in hydrological modelling, soil erosion studies and environmental simulations (Zhou \& Liu, 2004). River networks extracted from DEMs are defined as theoretical river networks (TRN) and can provide a suitable spatial network and hierarchical organisation to sort out river ecosystem information from the reach to the catchment level (Tarboton et al., 1991; Wang \& Yin, 1998; Clarke \& Burnett, 2003; Lin et al., 2006). All of the software packages used in the process of extracting river networks from DEMs exhibit two phases: first, reconditioning of the DEM's quality and removal of errors and second, determination of flow direction, flow accumulation and stream definition. To complete these steps, a number of processes, such as i) treatment of digital elevation depressions, ii) assignment of flow directions and iii) definition of drainage thresholds, need to be addressed using different algorithms, which vary depending on the software package employed. Nevertheless, automatic extraction does not provide the expected results in many cases, due mainly to the quality of the data sources (DEM lateral and vertical resolution) and the algorithms used during the extraction procedure.

Finally, a great deal of useful information about the physical structure of a river network may also be derived from a TRN, such as the contributing drainage area, basin shape, network patterns, network size, differences between confluent channels, drainage density, confluence density and local network geometry (e.g., Benda et al., 2004). Given the hierarchical organisation of rivers, these variables, along with other variables at different spatial scales, play an important role in determining many stream characteristics at smaller scales. In fact, many of these variables have been used to predict different physical habitat attributes of rivers, such as mesohabitat types (Montgomery \& Buffington, 1993; Wohl \& Merritt, 2005; Flores et al., 2006), substrate composition (Montgomery \& Buffington, 1998) or habitat quality for stream species (Lunetta et al., 1997; Burnett et al., 2007), among others (Montgomery \& Buffington, 1998; Strager et al., 2009; Vance-Borland et al., 2009). 
In the present study, we extracted TRNs from DEMs with spatial resolutions of 5 (TRN5), 25 (TRN25) and $90 \mathrm{~m}$ (TRN90) using the ArcHydro (Maidment, 2002), HEC-GeoHMS (USACE, 2000) and NetStream (Miller, 2003) software packages. The main objective of the study was to evaluate the effects of DEM spatial resolution and software algorithms on the structure and spatial precision of TRNs and on the discrimination ability of TRN variables in distinguishing between stream types. To achieve our goal, we compared (i) DEM slopes from DEMs with different spatial resolutions and sources, as slope is a fundamental parameter used in all flow direction algorithms (Wu et al., 2008); (ii) the spatial accuracy of the TRNs in relation to a control river network; (iii) the structure of the TRNs through analysis of the number of river segments, aver- age river segment length and total river length by stream order, drainage density and the mean upstream slope throughout the TRN; and (iv) the ability of variables derived from TRNs to discriminate among stream types classified according to flow type and substrate composition at the reach scale.

\section{MATERIALS AND METHODS}

\section{Study area}

The study area comprises the Saja $\left(483.2 \mathrm{~km}^{2}\right)$ and Besaya $\left(483.5 \mathrm{~km}^{2}\right)$ river catchments, located in the north of Spain in Cantabria (Fig. 1). As a consequence of its proximity to the ocean and steep topography, the basin presents a thermotemperate Atlantic climate on the coast that gra-

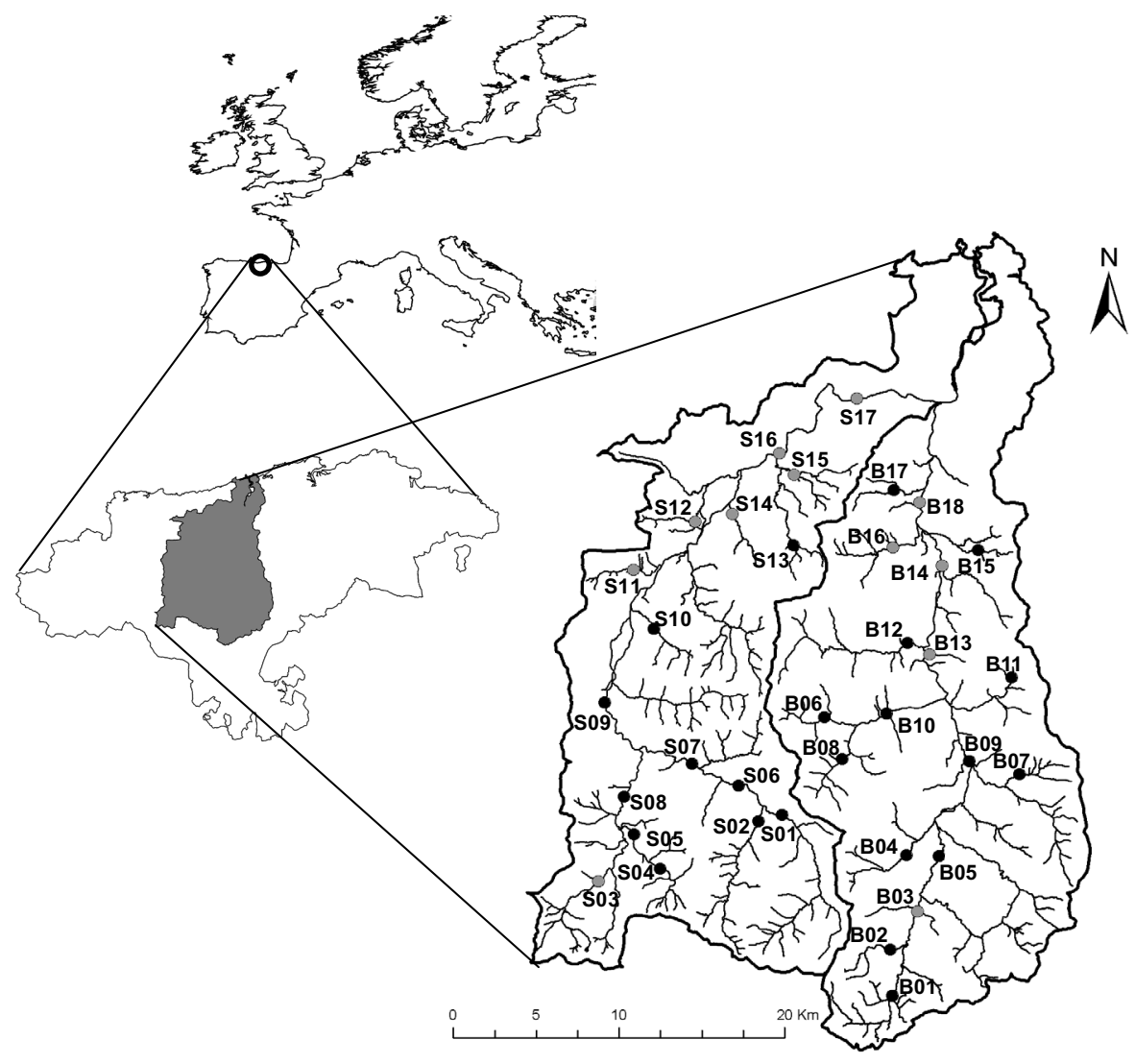

Figure 1. Location of the study catchments and sites (S: Saja; B: Besaya; •, RHS study sites and mean upstream slope calculation points; •, mean upstream slope calculation sites). Localización de las cuencas y puntos de estudio (S, Saja: B: Besaya; • puntos RHS y puntos de cálculo de pendiente media de la cuenca; •, puntos de cálculo de pendiente media de la cuenca). 
dually shifts towards a mountainous orotemperate climate at higher elevations (Rivas-Martínez et al., 2004). The average annual precipitation is $1344 \mathrm{~mm}$, and the annual average daily flow close to the river mouth is $22 \mathrm{~m}^{3} \mathrm{~s}^{-1}$ (Gobierno de Cantabria, 2005). A wet and a dry period can be differentiated, with the maximum average daily flows occurring in April $\left(34 \mathrm{~m}^{3} \mathrm{~s}^{-1}\right)$ and January $\left(35 \mathrm{~m}^{3} \mathrm{~s}^{-1}\right)$ and the minimum average daily flow being observed in September $\left(7 \mathrm{~m}^{3} \mathrm{~s}^{-1}\right)$. The basin lithology is predominantly detritic and calcareus, which cover $66 \%$ and $30 \%$ of the area, respectively. The climatic vegetation type is Atlantic deciduous forest comprised largely of a mixture of oaks (Quercus sp.), chestnuts (Castanea sativa) and beeches (Fagus sylvatica), although it should be noted that the Besaya catchment is largely deforested due to anthropogenic pressures. The Saja river starts at an altitude of $800 \mathrm{~m}$ and presents a total length of $54 \mathrm{~km}$, while the Besaya river starts at a $1200 \mathrm{~m}$ altitude and flows for $47 \mathrm{~km}$ until its connection with the Saja. Both headwater catchments present high slopes forming deep V-shape valleys.

\section{DEM comparison}

In this study, we used 3 DEMs for the study area, which were obtained from topographic maps and using remote sensing (satellite) techniques (Table 1). The different data sources selected offered different spatial resolutions and levels of accuracy, both horizontally and vertically (Table 1).

A comparison between the DEMs was performed in terms of slope, which is one of the most significant hydrological parameters (Clarke
\& Burnett, 2003; Wu et al., 2008). The techniques available to calculate slope from gridbased DEMs have been evaluated by several authors, who have reported that algorithms employing eight neighbouring cell values provide high-quality results and are more impervious to data error (Jones, 1998; Zhou \& Liu, 2004; Wu et al., 2008). Thus, the algorithm selected for calculation of slopes was the Horn method (Horn, 1981). Once the slopes were calculated for each raster, we produced frequency histograms for 20 classes ranging from 0 to $100 \%$ (one class for every $5 \%$ slope increment).

\section{TRN extraction methods and algorithm comparison}

We used the ArcHydro (AH; Maidment, 2002), Hec-GeoHMS. (HGH; 2000) and NetStream (NS; Miller, 2003) software packages to extract TRNs from the 3 DEMs available for our study area (AH-TRN5; AH-TRN25; AH-TRN90; HGH-TRN5; HGH-TRN25; HGH-TRN90; NSTRN5; NS-TRN25; NS-TRN90). These 3 software packages use different algorithms to address DEM depressions, determine flow direction and define drainage thresholds.

$\mathrm{AH}$ and HGH fill sinks using the Jenson and Domingue algorithm (1988), which modifies the DEMs by increasing the height value of the target cells and transforming the sinks on flat areas. However, this algorithm can produce more than one flow and hide useful information about the elevation of real depressions (Miller \& Burnett, 2008). On the other hand, NS includes depressions as real terrain characteristics allowing

Table 1. Characteristics of DEMs available for the Saja-Besaya catchment, northern Spain, Cantabria. Características de los Modelos Digitales de Elevación (MDE) disponibles para la cuenca del Saja-Besaya, Norte de España, Cantabria.

\begin{tabular}{lccc}
\hline & $5 \mathrm{~m}$ DEM & $25 \mathrm{~m}$ DEM & $90 \mathrm{~m}$ DEM \\
\hline Source data & Topographic Map & Topographic Map & Satellite \\
Development and distribution & $1: 5000$ & $1: 25.000$ & SRTM3 \\
Year of data acquisition & Cantabria Government & National Geographic Institute & NASA/USGS \\
Spatial Resolution & 2001 & 2000 & 2000 \\
Vertical Accuracy & $5 \mathrm{~m}$ & $25 \mathrm{~m}$ & $90 \mathrm{~m}$ \\
Extent & $0.5 \mathrm{~m}$ & $3 \mathrm{~m}$ & $10 \mathrm{~m}$ \\
Empty spaces & Local & National & $60^{\circ} \mathrm{N} \sim 56^{\circ} \mathrm{S}$ \\
\hline
\end{tabular}


the continuation of flow from the lowest pixel to the closest lower pixel under specific conditions (Miller \& Burnett, 2008). When these conditions are not achieved, the sinks are filled using the same approach as in $\mathrm{AH}$ and $\mathrm{HGH}$.

Regarding flow direction, $\mathrm{AH}$ and $\mathrm{HGH}$ employ the Deterministic 8 neighbourhood algorithm (D8) developed by Jenson \& Domingue (1988) based on the principle that water flows to areas with lower elevations. Thus, D8 assigns the flow direction of the target flow through comparison of the elevation of eight neighbourhood cells. When there is more than one cell with a lower height than the target cell, the flow direction is assigned following other secondary decision rules (Martz \& Garbrecht, 1998). A problem occurs when all of the neighbourhood cells have equal or higher elevations than the target cell, such as depressions or drains, causing the drainage location to fall in the centroid of the cell. The D8 does not allow dispersion of the flow to several cells, and therefore, the stream cannot be divided, setting up complex shapes, usually over flat areas. In NS software, the flow direction is assigned by two algorithms depending on the characteristics of the analysed area. If there are sufficient differences of elevation between cells, the algorithm selected is the Tarboton algorithm (Tarboton, 1997), whereas in flat areas, the Garbrecth and Martz algorithm (Garbrecht \& Martz, 1997) is used. The Tarboton algorithm represents the surface through eight triangles obtained from the DEM in a $3 \times 3$ cell analysis window. The flow direction is then assigned by the triangle with greatest slope in any direction (Miller \& Burnett, 2008). The other significant characteristic of the Tarboton algorithm is that it allows dispersion of the flow direction to one or two directions. The Garbrecth and Martz algorithm increases the value of the flat cells as a function of all of the surrounding cell values, varying the number of cells considered according to the size of the depression. Subsequently, the algorithm builds gradients that allow the definition of flow patterns and then applies the breaching algorithm, which removes the surrounding values of a depression as overestimated products (Martz \& Garbrecht, 1998).
Finally, for definition of drainage thresholds, $\mathrm{AH}$ and HGH use a constant value by default, considering $1 \%$ of the maximum accumulated flow as an optimal drainage threshold (Maidment, 2002). NS, in turn, uses an approach in which the drainage threshold can vary along the DEM based on a slope-surface analysis (Miller \& Burnett, 2008). In this study however, to establish reliable comparisons between methods, we have set the channel initiation criteria to $1 \mathrm{~km}^{2}$ for all river network extraction methods, which is a conservative value considering that heads of channels can occur in drainages of less than a tenth of a square kilometre in humid mountain terrains (Benda \& Dunne, 1997).

Additionally, to compare some of the attributes of the 9 TRNs, we used a digitised control river network (CRN) derived from 1:5000 scale Cantabria Government Cartography. This data layer was checked for errors and rectified using digital images from 2005. All of the segments that were not included in the CRN were eliminated from each TRN, which allowed us to make more robust comparisons, as all TRNs included a more similar number of order 1 streams.

\section{TRN spatial accuracy}

One of the most critical attributes of TRNs is the spatial configuration in terms of spatial location and drainage extent (Clarke \& Burnett, 2003). For this reason, we evaluated the degree of coincidence between each of the 9 resulting TRNs with the CRN by applying buffers of $5,15,20,30,40,50$ and $60 \mathrm{~m}$ to the TRNs and evaluating the percentage of vertexes from the CRN that fell inside each of the buffers. The CRN was composed of 77368 vertexes. We considered that a higher percentage of vertexes in narrower buffers was indicative of a higher spatial location precision.

The spatial accuracy of the 9 TRNs was compared in steep and flat areas separately. To do this, we reclassified each pixel of the most accurate DEM $(5 \mathrm{~m})$ into 2 groups by means of the Jenk natural breaks method (Jenk, 1967). The spatial analyst of ArcGis (ESRI, 2009) was used to carry out the analysis. Thus, slope class 1 rep- 
resented low gradient pixels, while slope class 2 represented high gradient pixels. Subsequently, each of the 196 subcatchments associated with the CRN were classified as steep if $\geq 60 \%$ the area was occupied by pixels of slope class 2 and as flat if $\geq 60 \%$ was occupied by pixels of slope class 1. Next, six subcatchments of each type containing a similar number of CRN vertexes $( \pm 10 \%)$ were selected. We assessed the degree of coincidence between each of the 9 TRNs and the CRN by applying buffers of 5 and $60 \mathrm{~m}$ to the TRNs and evaluating the number of vertexes from the CRN that fell inside each of the buffers for flat and steep subcatchments independently. Kruskall-Wallis (K-W) tests followed by Bonferroni corrections were performed to test for significant differences in the number of vertexes for the different TRNs and buffers. Multiple comparison tests after $\mathrm{K}-\mathrm{W}$ tests were carried out to test for significant differences between each pair of TRNs. All analyses were carried out using R (version 2.7.1; R Development Core Team, 2008).

\section{TRN structure}

The structure of the 9 TRNs was compared based on the number of river segments, average river segment length and total river length by stream order, drainage density and mean upstream slope. The TRN segments were considered to be the river stretch included between two tributaries or between the river source and the confluence with another segment. Segments were classified according to Strahler (1957) using the FLOW version 9.2 tool from the ArcHydro software package (Maidment, 2002).

The total and the average river segment length by stream order are the sum and the mean value of the lengths of river segments with same stream order, respectively. These variables and the number of river segments by stream order are directly associated with the accuracy of the location, the shape and the size of the river network (Leopold et al., 1964; Wang \& Yin, 1998). Drainage density was calculated for each TRN as the ratio between total stream length and total catchment area. It also represents a measure of the balance between erosion power and erosion resistance and depends on catchment lithology, soil permeability and plant coverage among other catchment parameters (Montgomery \& Buffington, 1993; Colombo et al., 2007). These 4 structure parameters were compared with those obtained for the CRN. Finally the mean upstream slope of a segment was calculated as the average segment slope weighted by the length of the segments situated upstream of the target segment, i.e., the mean slope of the river at an outlet (final segment). Each segment slope was calculated as the difference in altitude from the lowest to the highest points in the segment divided by the segment length. Differences between the mean upstream slopes calculated for the 9 TRNs were evaluated at 35 points (17 in the Saja catchment and 18 in the Besaya catchment; Fig. 1). The differences were analysed considering tributary and mainstem segments independently.

\section{Discrimination ability of $\mathrm{TRN}$ variables}

To investigate the effect of TRN structure and spatial accuracy on the ability of derived TRN variables to discriminate between reach types classified according to habitat characteristics, we selected 6 TRNs extracted with $\mathrm{AH}$ and NS from $5 \mathrm{~m}$ (AH-TRN5 and NS-TRN5), $25 \mathrm{~m}$ (AHTRN25 and NS-TRN25) and $90 \mathrm{~m}$ (AH-TRN90 and NS-TRN90) DEMs. The predictor variables we derived from each TRN were segment slope (Ss), mean upstream slope (Ms), sinuosity ( $\mathrm{Sn}$ ), drainage area (Da) and specific stream power (W). W is a combination of channel-segment slope and the contributing area that reflects the balance between eroding and resisting forces at a site (Flores et al., 2006).

River Habitat Survey (RHS; Raven et al., 1997) was carried out in summer 2008 and spring 2010 at 23 sites within the Saja-Besaya catchment (Fig. 1). The RHS was designed to yield reliable information on the physical structure of a $500 \mathrm{~m}$ stretch of river in a format suitable for statistical analysis (Fox et al., 1998). The spotchecks section of the RHS is a series of $1 \mathrm{~m}$ wide transects across the channel at $50 \mathrm{~m}$ intervals where bank and channel physical structure, man-made modifications, land uses and vege- 
tation structure are recorded (Naura \& Robinson, 1998). Sites were grouped according to flow type and channel substrate composition derived from the RHS by performing a cluster analysis using Manhattan distances and Ward's method. This analysis was performed using the STATISTICA software package (Version 6.0; StatSoft Inc., 1994). Flow type depends largely on water velocity, depth and flow direction (Raven et al., 1997), which together with the substrate composition, play important roles in determining habitat suitability for many stream animals (Lamoroux et al., 1998; Martinez-Capel \& Garcia de Jalón, 1999; Death \& Joy, 2004; Eedy \& Giberson, 2007; Parasiewicz, 2008) and plants (Buffagni et al., 2000; Franklin et al., 2008). Subsequently, TRN segments were named according to the group assigned to their corresponding RHS site.

Stepwise discriminant analyses with Mahalanobis distance were used to discriminate the group membership of the 23 segments into the groups set up previously. All independent variables were log transformed to improve compliance with discriminant analysis assumptions. We performed one discriminant analysis for the segments of each of the 6 TRNs separately. Crossvalidation (leave-one-out) was used to evaluate the performance of the classification, which was used as a mean of comparing the ability of the 6 TRNs to discriminate between groups. Discriminant analysis was performed using the SPSS software package (SPSSInc., 2009).

\section{RESULTS}

\section{DEM comparison}

The distribution of cells among slope classes showed similar patterns for all of the DEMs, regardless of their spatial resolution or data source (Fig. 2). Cell frequency increased from the $5-10 \%$ slope class up to the $20-25 \%$ slope class, followed by a gradual decrease until the 95-100 \% slope class.

DEMs with lower resolutions produced lower average slopes. Thus, the 5 and $25 \mathrm{~m}$ DEMs produced practically the same slope histogram, with

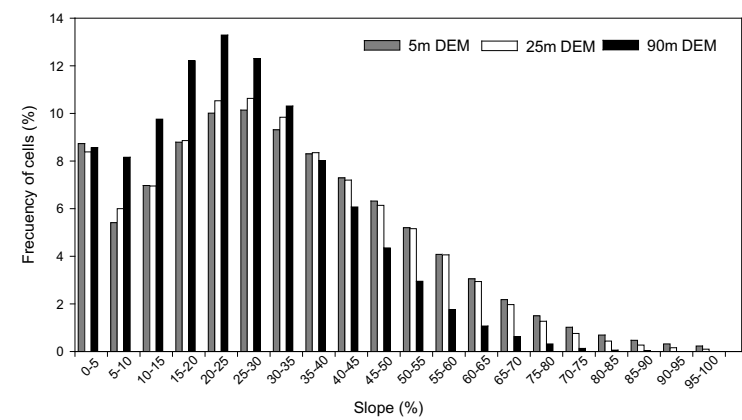

Figure 2. Frequency distribution of slopes for every $5 \%$ increase for the 5, 25 and $90 \mathrm{~m}$ spatial resolution DEMs. Distribución de frecuencias de pendientes con incrementos del $5 \%$ para los MDTs con resolución espacial de de 5, 25 y $90 \mathrm{~m}$.

greater frequencies of cells in the high slope classes than the $90 \mathrm{~m}$ DEM (Fig. 2). The 5 and $25 \mathrm{~m}$ DEMs presented $10 \%$ of cells with slopes higher than $60 \%$, while this percentage was reduced to $1.8 \%$ for the $90 \mathrm{~m}$ DEM. Moreover, the $90 \mathrm{~m}$ DEM did not present any cell with a slope higher than $70 \%$. In contrast, the $90 \mathrm{~m}$ DEM presented more than $70 \%$ of cells falling below the $35-40 \%$ slope class, while the 5 and $25 \mathrm{~m}$ DEMs presented just 50 and $58 \%$ of cells below this slope class, respectively (Fig. 2).

\section{TRN spatial accuracy}

Both DEM spatial resolution and the software package used had effects on the spatial accuracy of the TRNs. Thus, NS generated more positionally accurate streams than $\mathrm{AH}$ and $\mathrm{HGH}$ when using the 5 and $25 \mathrm{~m}$ DEMs (Fig. 3). On the other hand, the TRNs extracted with AH and HGH from the 5 as well as from the $25 \mathrm{~m}$ DEMs presented a very similar spatial accuracy compared to the CRN. These differences reached $20 \%$ when applying a buffer of $5 \mathrm{~m}$ and decreased to less than $10 \%$ when applying buffers wider than $20 \mathrm{~m}$. The least accurate TRNs were obtained when using the $90 \mathrm{~m}$ DEM, regardless of the software employed. In this case, NS produced the worst result, although the differences reached a maximum of $8 \%$ (Fig. 3).

The CRN presented averages of $205 \pm 3$ (standard error) and $331 \pm 12$ vertexes in the 6 subcatchments of flat and steep slope classes, respectively. The TRNs extracted from the 5 DEM 


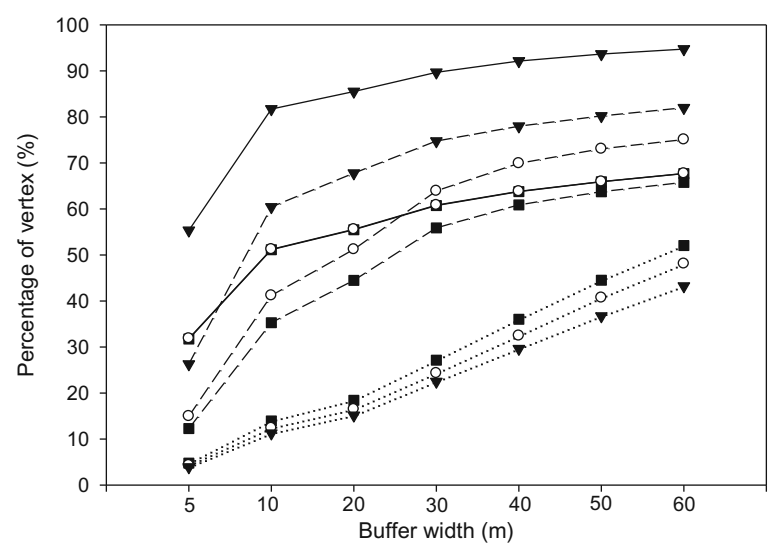

Figure 3. Percentage of CNR vertexes contained within different buffers of the TRNs extracted from $5(-), 25(--)$ and $90 \mathrm{~m}$ (.....) spatial resolution DEMs using the ArcHydro (ם), HecGeoHMS (o) and NetStream (v) software packages. Porcentaje de vértices de la red fluvial control contenidos dentro de la anchura de diferentes buffers de las RFTs extraídas de MDEs con resoluciones espaciales de 5 (-), 25 (- - -), y $90 \mathrm{~m}$ (.....) mediante los paquetes informáticos ArcHydro (ם), HecGeoHMS (o) y NetStream ( $\mathbf{v}$ ).

presented almost 10 times more vertexes on average within the $5 \mathrm{~m}$ buffer of the CRN (53\%) than TRNs extracted from the 90 m DEM (5\%) in steep areas (Table 2). The differences when applying a $60 \mathrm{~m}$ buffer were not as evident.

In addition, NS-TRN5 exhibited 3 times more vertexes within the $5 \mathrm{~m}$ buffer of the CRN (17\%) than any TRNs extracted from the $90 \mathrm{mDEM}(5 \%)$ in flat areas (Table 2). Nevertheless, we did not find significant differences in this area (Table 2).

\section{TRN structure comparison}

All of the TRNs extracted and the CRN reached order 5 (Fig. 4). However, with the exception of $\mathrm{HGH}-25, \mathrm{AH}$ and $\mathrm{HGH}$ generated order 5 streams after the Saja and Besaya confluence, while NS generated order 5 streams after the Saja and Argonza confluence (Point S09; Fig. 1), which agreed better with the CRN structure.

$\mathrm{AH}$ and $\mathrm{HGH}$ generated TRNs with fewer segments than the CRN, encountering greater differences for smaller stream orders (Fig. 4). In addition, both software packages generated TRNs with a very similar number of segments in each stream order, regardless of DEM resolution. However, NS-TRN5 and NS-TRN25 were more similar to the CRN than the other TRNs (Fig. 4). NS-TRN5 exhibited a slightly greater number of segments, while NS-TRN25 had a lower number of segments than the CRN.

Regarding the average segment length, the CRN showed a slight increase in values from stream order $1(978 \mathrm{~m})$ to $4(1393 \mathrm{~m})$ and a steeper increase from stream order 4 to 5 (2827 m; Fig. 4). All TRNs extracted with NS and HGH-TRN25 presented this pattern, while the TRNs extracted with $\mathrm{AH}$ and $\mathrm{HGH}$ did not exhibit a increase of values between orders 4 and 5 (Fig. 4.). In addition, the average segment length of NS-TRNs, HGH-TRN25 and the CRN for each stream order were more similar to each other than to those of the TRNs obtained with $\mathrm{AH}$ and $\mathrm{HGH}$.

Table 2. Mean number and standard error of CRN vertexes that fall inside the 5 and $60 \mathrm{~m}$ buffers for 9 TRNs in slope class 1 and 2 subcatchments. Results of Kruskal-Wallis and multiple comparison tests after Kruskal-Wallis applying Bonferroni corrections testing for differences between 9 TRNs (bold $=p<0.025$ ). Underlined TRNs were not significantly different. When Kruskal-Wallis revealed non-significant differences, multiple comparison tests were not carried out. (Class $=$ Subcatchment classification; Buff $=$ Buffer wide; $\mathrm{A}=$ Archydro; $\mathrm{H}=\mathrm{HecGeoHMS} ; \mathrm{N}=$ NetStream). Media y error estándar del número de vértices de la red fluvial control contenidos dentro de la anchura delimitada por los buffer de 5 y 60 m obtenidos a partir de 9 RFT para las subcuencas de las clases de pendiente 1 y 2. Resultados del test de Kruskal-Walis y del test de múltiples comparaciones después de Kruskal-Wallis una vez aplicadas las correcciones de Bonferroni para testar las diferencias entre las 9 RTF (negrita $=\mathrm{p}<0.025$ ). Las RFT subrayadas no fueron significativamente diferentes. Si el test de Kruskal-Walis reveló que las diferencias no fueron significativas el test de múltiples comparaciones no se realizó. (Class = Clase de pendiente; Buff = Anchura del buffer; A = Archydro; H=HecGeoHMS; $N$ = NetStream).

\begin{tabular}{|c|c|c|c|c|c|c|c|c|c|c|c|c|}
\hline Class & Buff & A5 & H5 & N5 & A25 & $\mathbf{H} 25$ & N25 & A90 & H90 & N90 & H d.f. $=8$ & Multiple comparision test after $\mathrm{K}-\mathrm{W}$ \\
\hline Flat & 5 & $18 \pm 6$ & $18 \pm 6$ & $35 \pm 8$ & $7 \pm 3$ & $10 \pm 5$ & $14 \pm 5$ & $11 \pm 5$ & $12 \pm 4$ & $11 \pm 4$ & 10.42 & \\
\hline Flat & 60 & $144 \pm 28$ & $144 \pm 28$ & $153 \pm 19$ & $76 \pm 23$ & $78 \pm 23$ & $79 \pm 23$ & $123 \pm 15$ & $121 \pm 14$ & $75 \pm 17$ & 13.05 & \\
\hline Steep & 5 & $145 \pm 17$ & $145 \pm 17$ & $220 \pm 18$ & $52 \pm 8$ & $72 \pm 10$ & $104 \pm 13$ & $21 \pm 5$ & $16 \pm 4$ & $13 \pm 2$ & 45.26 & N5 A5 H5 A25 H25 N25 A90 H90 N90 \\
\hline Steep & 60 & $255 \pm 24$ & $255 \pm 24$ & $329 \pm 11$ & $249 \pm 21$ & $275 \pm 18$ & $323 \pm 10$ & $206 \pm 20$ & $186 \pm 20$ & $171 \pm 19$ & 29.98 & N5 N25 A5 H5 A25 H25 A90 H90 N90 \\
\hline
\end{tabular}



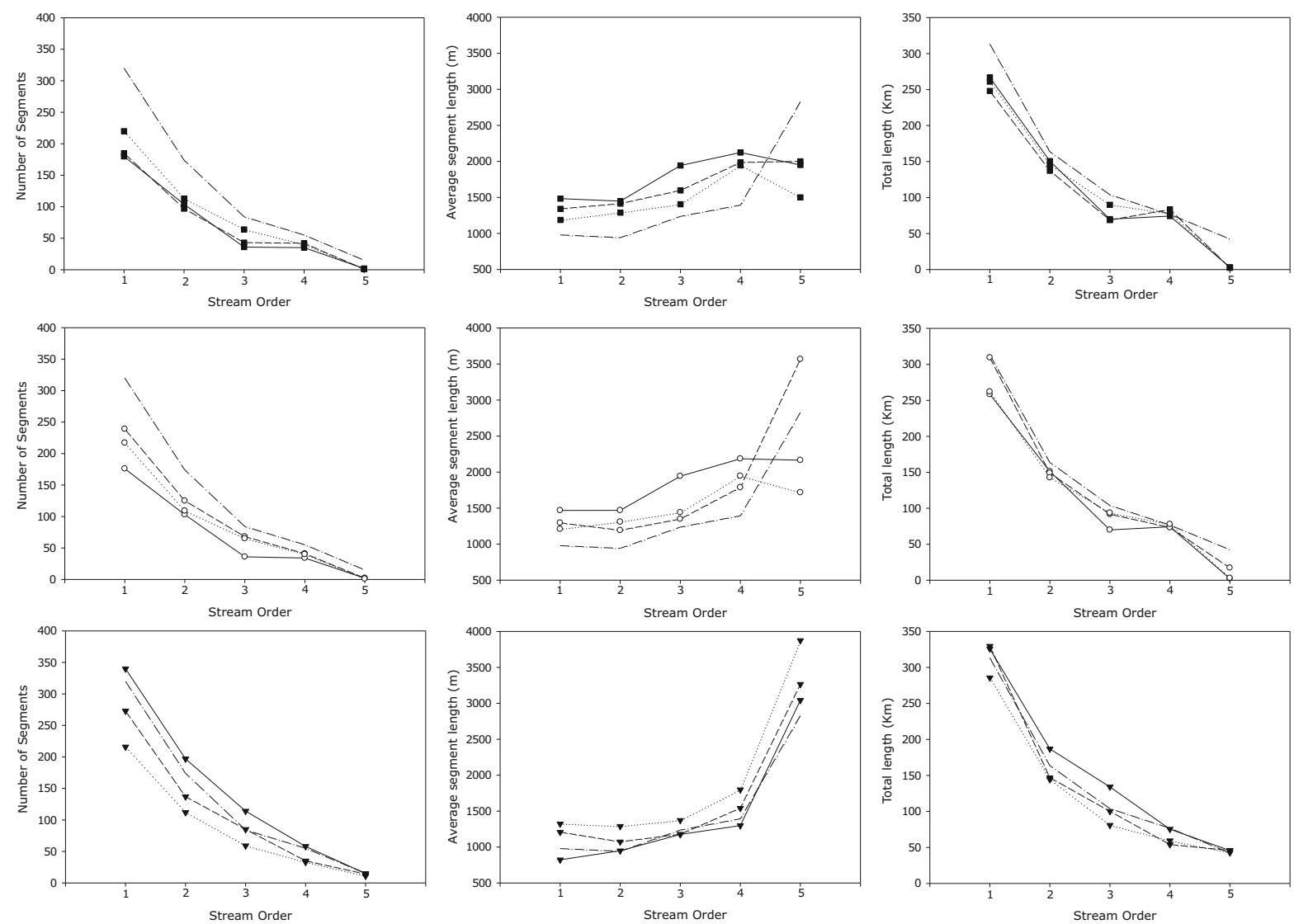

Figure 4. Number of segments, average segment length and total segment length by stream order of the control river network (-·-) and TRNs extracted from 5 (-), 25 (- - ) and $90 \mathrm{~m}$ (.....) DEMs using the ArcHydro (घ), HecGeoHMS (o) and NetStream (v) software packages. Número de segmentos, longitud media de segmentos y longitud total de los segmentos de cada orden fluvial de la red fluvial control (-.-) y de las RFT extraídas de MDEs con resoluciones espaciales de 5 (-), 25 (- - -) y 90 m (.....) mediante los paquetes informáticos ArcHydro (ם), HecGeoHMS (o) y NetStream ( $\mathbf{v}$ ).

The total segment length patterns were very similar both between the CRN and the TRNs and among all of the TRNs, independently of the DEM spatial resolution or the software used (Fig. 4). The greatest differences were found between the CRN and the TRNs extracted with $\mathrm{AH}$ and $\mathrm{HGH}$, especially when comparing order 1 and 5 streams (Fig. 4).

CRN presented a drainage density of $0.75 \mathrm{~km}$ $\mathrm{km}^{-2}$ (Fig. 5). The TRNs extracted with $\mathrm{AH}$ and $\mathrm{HGH}$, except for HGH-TRN25 $\left(0.68 \mathrm{~km} \mathrm{~km}^{-2}\right)$, showed very little variation in drainage density, ranging from 0.58 to $0.62 \mathrm{~km} \mathrm{~km}^{-2}$ (Fig. 5). In contrast, NS showed an increase of the drainage density with increased DEM resolution. Thus, NS-TRN5 and NS-TRN25 presented drainage densities of 0.82 and $0.72 \mathrm{~km} \mathrm{~km}^{-2}$, respectively (Fig. 5).

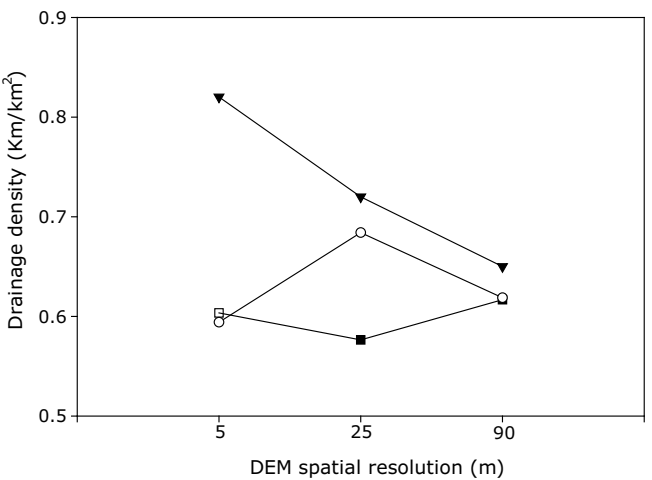

Figure 5. Drainage density of TRNs extracted using the ArcHydro (ם), HecGeoHMS (o) and NetStream ( $\mathbf{v}$ ) software packages. The drainage density of the CRN was $0.75 \mathrm{~km} \mathrm{~km}^{-2}$. Densidad de drenaje de las 12 RTF extraídas mediante los paquetes informáticos ArcHydro (匹), HecGeoHMS (o) y NetStream ( $\mathbf{\nabla})$. La densidad de drenaje de la red fluvial control fue de $0.75 \mathrm{~km} \mathrm{~km}^{-2}$. 
The mean upstream slopes were lower for the TRNs obtained from the $5 \mathrm{~m}$ DEM and increased as DEM resolution decreased (Fig. 6). Although all of the TRNs presented very similar patterns and values, NS-TRN5 presented higher mean upstream values than AH-TRN5 and HGH-TRN5, while NS-TRN25 and HGH-TRN25 presented higher values than AH-TRN25.

\section{Discrimination ability of TRN variables}

Cluster analysis of the RHS sites showed 4 different groups at the chosen cut-off level (Fig. 7). Group 3 (G3) and 4 (G4) were more similar to each other than to Groups 1 (G1) and 2 (G2). Thus, to increase and homogenise the number of sampling sites per group and improve subse-
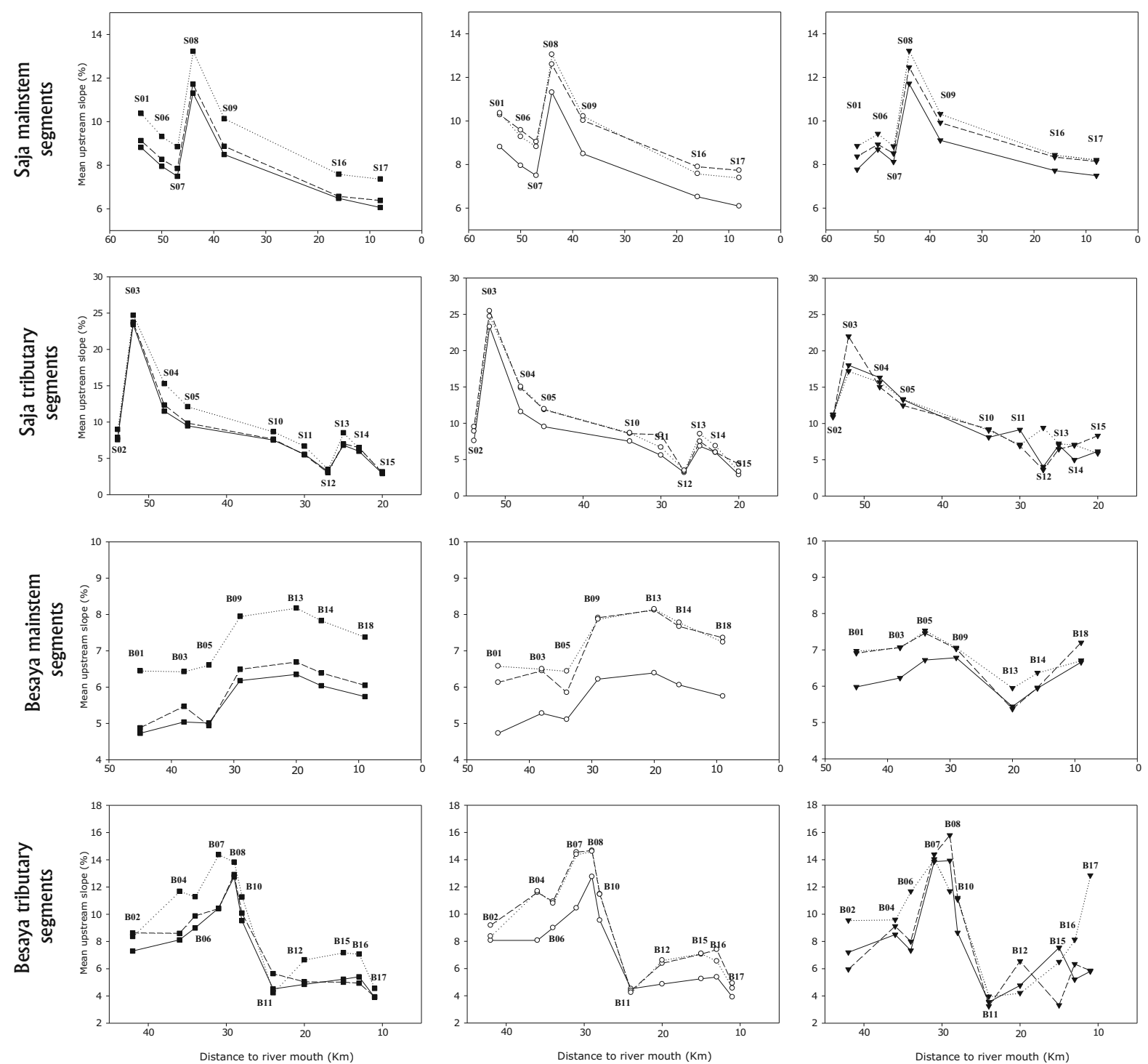

Figure 6. Mean upstream slope calculated at 36 study sites for TRNs extracted from 5 (-), 25 (- - -) and $90 \mathrm{~m}(\ldots .$.$) spatial$ resolution DEMs using the ArcHydro ( $\mathbf{(})$, HecGeoHMS (o) and NetStream ( $\mathbf{v})$ software packages. Pendiente media de rio calculada en 36 puntos de estudio situados en las RFT extraídas de MDE con resoluciones espaciales de 5 (一), 25 (- - -) y 90 m (.....) mediante los paquetes informáticos ArcHydro ( $\mathbf{\square})$, HecGeoHMS (o) y Netstream ( $\mathbf{v})$. 


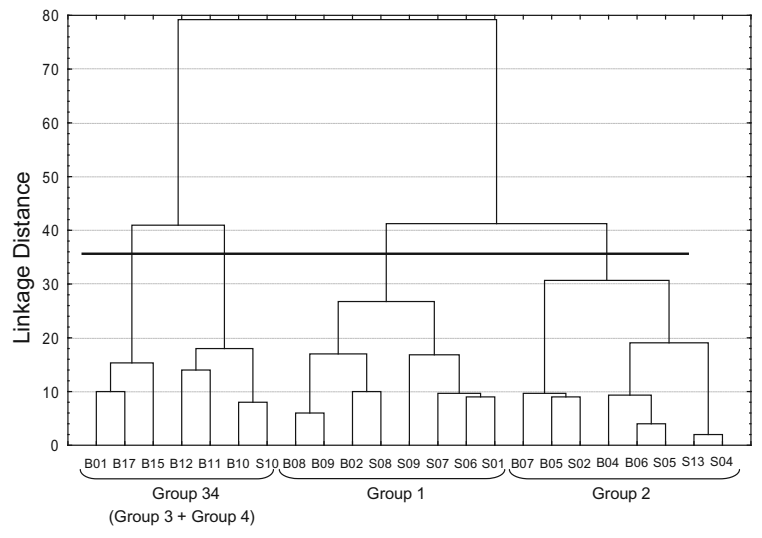

Figure 7. Cluster dendrogram based on a dissimilarity matrix of Manhattan distances calculated from the flow type and substrate size for sites sampled by RHS in the Saja and Besaya catchments. The line indicates the linkage distance cut-off level to determine cluster groups. Dendrograma del cluster basado en una matriz de disimilaridad de distancias Manhattan de los tipos de flujo y tamaño de sustrato en los puntos muestreados mediante RHS en las cuencas del Saja y del Besaya. La línea indica el nivel de corte seleccionado para definir los grupos.

quent analyses, G3 and G4 were joined evenly in a group (Group 34; Fig. 7). G1 was composed of high altitude sites in the mainstem, while Group 2 was composed of high altitude sites situated in tributaries. G34 was composed mainly of sites in middle and low altitude tributaries, most of which were situated in the Besaya catchment (Fig. 1).

Independent of the TRN, the segment slope was higher in G2, while G1 and G34 showed very similar values. Group 34 presented the lowest mean upstream slope, whereas no differences were observed between G1 and G2. Sinuosity showed a decrease in values from G1 to G34. G1 presented the highest average drainage area.

Stepwise discriminant analyses revealed that both software and DEM spatial resolution played important roles in the selection of the predictor variables and in the classification rates. The variables $\mathrm{W}, \mathrm{Da}$ and $\mathrm{Ss}$ were the independent variables that best discriminated between groups for NS-TRN5 and NS-TRN25, while Da was the only independent variable when the analysis was carried out with NS-TRN90 (Table 3). Additionally, W, Da and Ms were the predictor variables when using AH-TRN5 and AH-TRN25, while

Table 3. Cross-validation (Leave-one-out) classification results for the discriminant analysis using independent variables derived from TRNs extracted from 5, 25 and 90 m DEMs using the ArcHydro (AH) and NetStream (NS) software packages. The variables shown include stream power (W), drainage area (Da), segment slope (Ss), and mean upstream slope (Ms). Resultados de la clasificación mediante validación cruzada del análisis discriminante utilizando variables independientes derivadas de las RFTs extraídas a partir de MDE con resoluciones espaciales de 5, 25 y 90 m, mediante los paquete informáticos ArcHydro (AH) y NetStream (NS). Se incluyen las variables energía del río (W); área de drenaje (Da); pendiente del segmento (Ss) y pendiente media $(M s)$.

\begin{tabular}{|c|c|c|c|c|c|c|c|}
\hline \multirow{2}{*}{ Software } & \multirow{2}{*}{$\begin{array}{c}\text { DEM } \\
\text { resolution }\end{array}$} & \multirow{2}{*}{$\begin{array}{l}\text { Predictor } \\
\text { Variables }\end{array}$} & \multirow{2}{*}{ Group } & \multicolumn{3}{|c|}{ Predicted group } & \multirow{2}{*}{$\begin{array}{c}\text { Overall } \\
\text { Clasification }(\%)\end{array}$} \\
\hline & & & & 1 & 2 & 34 & \\
\hline \multirow{4}{*}{ NS } & \multirow{4}{*}{5} & \multirow{4}{*}{$\mathrm{W}, \mathrm{Da}, \mathrm{Ss}$} & 1 & 75.0 & 25.0 & 0 & \multirow{4}{*}{78.30} \\
\hline & & & 2 & 0 & 87.5 & 12.5 & \\
\hline & & & 34 & 14.3 & 14.3 & 71.4 & \\
\hline & & & 1 & 75.0 & 25.0 & 0 & \\
\hline \multirow[t]{3}{*}{ NS } & \multirow[t]{3}{*}{25} & \multirow[t]{3}{*}{$\mathrm{W}, \mathrm{Da}, \mathrm{Ss}$} & 2 & 12.5 & 75.0 & 12.5 & \multirow[t]{3}{*}{69.60} \\
\hline & & & 34 & 14.3 & 28.6 & 57.1 & \\
\hline & & & 1 & 75.0 & 12.5 & 12.5 & \\
\hline \multirow[t]{3}{*}{ NS } & \multirow[t]{3}{*}{90} & \multirow[t]{3}{*}{$\mathrm{Da}$} & 2 & 12.5 & 75.0 & 12.5 & \multirow[t]{3}{*}{52.20} \\
\hline & & & 34 & 28.6 & 71.4 & $\mathbf{0}$ & \\
\hline & & & 1 & 75.0 & 25.0 & 0 & \\
\hline \multirow[t]{3}{*}{$\mathrm{AH}$} & \multirow[t]{3}{*}{5} & \multirow[t]{3}{*}{$\mathrm{W}, \mathrm{Da}, \mathrm{Ms}$} & 2 & 12.5 & 75.0 & 12.5 & \multirow[t]{3}{*}{78.30} \\
\hline & & & 34 & 14.3 & 0 & 85.7 & \\
\hline & & & 1 & 75.0 & 25 & 0 & \\
\hline \multirow[t]{3}{*}{$\mathrm{AH}$} & \multirow[t]{3}{*}{25} & \multirow[t]{3}{*}{$\mathrm{W}, \mathrm{Da}, \mathrm{Ms}$} & 2 & 12.5 & 75.0 & 12.5 & \multirow[t]{3}{*}{73.90} \\
\hline & & & 34 & 14.3 & 14.3 & 71.4 & \\
\hline & & & 1 & 62.5 & 37.5 & 0 & \\
\hline \multirow[t]{2}{*}{$\mathrm{AH}$} & \multirow[t]{2}{*}{90} & \multirow[t]{2}{*}{ Ss, Ms } & 2 & 12.5 & 75.0 & 12.5 & \multirow[t]{2}{*}{69.50} \\
\hline & & & 34 & 28.6 & 0 & 71.4 & \\
\hline
\end{tabular}


these variables were Ss and Ms when using NSTRN90. Cross-validation analysis showed that NS-TRN5, NS-TRN25 and NS-TRN90 achieved $78.3 \%, 69.6 \%$ and $52.2 \%$ overall correct classifications, respectively. For these three TRNs, Group 3 showed the highest misclassification rates $(71.4,57.1$ and $0 \%$; Table 3$)$. Furthermore, the cross-validation analysis showed that AHTRN5, AH-TRN25 and AH-TRN90 achieved $78.3 \%, 73.90 \%$ and $69.50 \%$ of overall correct classifications, respectively (Table 3 ). The group with the highest misclassification rates varied depending on the TRN used.

\section{DISCUSSION}

The results obtained in this study revealed that DEM spatial resolution, the data source and the raster creation process were all important factors that influenced the terrain characteristics derived from the DEMs (e.g., slope) and the extracted TRN spatial accuracy, structure and ability to discriminate stream type membership according to habitat characteristics. The DEMs employed in this study were derived from different remote sensing techniques as well as different topographic data sources, and consequently, they should have produced different results. However, some analyses yielded similar outcomes regardless of the DEM involved, as has been pointed out in other studies concerned with DEM spatial resolution (Wang \& Yin, 1998; Clarke \& Burnett, 2003; Wu et al., 2008). Furthermore, it should be noted that the CRN was derived from digital images captured in 2005, while the TRNs were extracted from data acquired in 2000 and 2001. This could represent a source of error if changes in river morphology due to natural morphological processes (e.g., spates) occurred during this period. Nevertheless, we can assume that given the proximity of the dates of data acquisition, the comparison between the TRNs presented the same error with respect to the CRN. Finally, we proved that the methods and algorithms used to extract TRNs from DEMs may also be an important source of differences in the extracted river network characteristics.

\section{DEM comparison}

Higher resolution DEMs represent terrain slope better than lower resolution models (Zhang et al., 1999; Clarke \& Burnett, 2003), mainly because smoother surfaces and smaller slopes are obtained with less accurate DEMs (Kienzle, 2004; Wu et al., 2008; Li \& Wong, 2010). Wu et al. (2008) found that the effect of DEM spatial resolution is more pronounced in steeper landscapes. Moreover, a higher resolution DEM does not assure greater slope accuracy unless a DEM with high vertical accuracy data is used (Zhou $\&$ Liu, 2004). Thus, for a steep terrain, such as the Saja-Besaya catchment, we would expect that different DEM resolutions and vertical accuracies will cause differences in the derived slopes; however, the results of the 5 and $25 \mathrm{~m}$ DEMs were quite similar. This result is in accord with the conclusions of Kienzle (2004), who asserted that grid cell sizes over $25 \mathrm{~m}$ are not able to identify steep slopes successfully. In this study, the differences of slope recorded between the 5 and $25 \mathrm{~m}$ DEMs and the $90 \mathrm{~m} \mathrm{DEM}$ were the largest, which might be related to the type of data source (i.e., topographic versus remote sensing) and DEM generation process, rather than to DEM spatial resolution or vertical accuracy. Nevertheless, slope histograms may mask some differences between resolutions because they are unable to identify the direction of the differences (Clarke \& Burnett, 2003).

\section{TRN spatial accuracy}

Our results showed that DEM spatial resolution had a greater effect than the extraction method used on TRN spatial accuracy (Fig. 3). Other authors (Wang \& Yin, 1998; Clarke \& Burnett, 2003) have also identified DEM resolution as one of the mayor factors affecting the accuracy of stream network extraction. Moreover, it has been found that in steep areas, the ability to delineate streams improves according to DEM spatial resolution (Wang \& Yin, 1998). Our results appear to corroborate this, as the 5 and $25 \mathrm{~m} \mathrm{DEMs} \mathrm{gen-}$ erated a more spatially accurate TRN than the 90 m DEM. Nevertheless, the differences between 
the TRNs were greatly reduced when applying a $60 \mathrm{~m}$ buffer, indicating that the TRNs delineated from the $90 \mathrm{~m}$ DEM were not far from the CRN.

Among the investigated software packages, NS generated better results than the others, especially when using a high resolution DEM (Fig. 3). Our results indicated that both the Tarboton algorithm, used by NS, and the D8 algorithm, used by $\mathrm{AH}$ and $\mathrm{HGH}$, are powerful tools for delineating streams in steep areas. Nevertheless, NS-TRN5 and NS-TRN25 exhibited a higher drainage density because of the larger number of order 1 and 2 streams produced (Fig. 4). The lower accuracy of other TRNs was not only related to inaccuracy in the delineated segments but also to the smaller number of segments delineated. In flat areas, NS generated TRNs that were more similar to the CRN than the others software packages when using high resolution DEMs; however, the differences were low and not significant. This was contrary to our expectations, as NS software includes a group of algorithms (Garbrecht \& Martz, 1997; Tarboton, 1997) to deal with complex terrain structures associated with flat areas (i.e., puddles, sinks, depressions or bifurcations; Miller, 2003; Miller \& Burnett, 2008). Thus, our results show that it was not possible to produce highly accurate streams networks in flat areas, regardless of the software used or DEM scale, which is in accord with the conclusions of other studies on high complexity terrain (Wang \& Yin, 1998). Most of the land surface parameterisation algorithms implemented in the available software were developed one or two decades ago. Some of them may have been refined, but not radically changed (Vaughan et al., 2009). Moreover, the significant amount of research currently being carried out (e.g., Lin et al., 2006; Zhu et al., 2006; Jana et al., 2007) show that the extraction of river networks in flat terrains is still an unsolved problem.

\section{TRN structure comparison}

Our results highlighted the dependence of TRN characteristics on the software package used to extract the river network and, to a lesser extent, on DEM spatial resolution. NS produced net- works with a greater number of segments and a lower average segment length by stream order than $\mathrm{AH}$ and $\mathrm{HGH}$. The structure of NS-TRNs showed the best agreement with the CRN, generating as many order 1 segments as the CRN, especially when using the $5 \mathrm{~m}$ DEM. Moreover, our results showed that NS generated TRNs with higher mean upstream slopes than those extracted with $\mathrm{AH}$ and $\mathrm{HGH}$, which could be related to the greater density of source segments. Order 1 segments presented the steepest slopes; therefore, the greater the number of order 1 segments, the higher the mean upstream slope in a downstream segment will be. These differences could be related to the use of a constant drainage threshold, which may vary the delineation of source segments from one software package to the other. For example, NS uses variables such as those based on slope-surface analysis (Miller \& Burnett, 2008) to define the drainage threshold, which may have increased the number of order 1 segments and, thus, the drainage density. A possible solution to obtain a network more similar to the CRN would be to perform a classification of the study area based on its capability to hold drainage, which depends on factors such as lithology, permeability or vegetation cover (Leopold et al., 1964). Vogt et al. (2003) developed a methodology in which landscape characteristics were used to perform classification according to the terrain capacity to contain lower or higher drainage densities, and thus, a singular drainage threshold was assigned to each landscape class.

DEM spatial resolution did not affect the number of stream segments or total segment length by stream order when using $\mathrm{AH}$ and $\mathrm{HGH}$. However, DEM spatial resolution produced small differences in river network characteristics when using NS. In this regard, Wang \& Yin (1998) and Da Paz et al. (2008) found that DEMs with lower spatial resolution underestimate total stream length and the number of segments, as they could not detect some small streams because of reduced vertical resolution. In addition, $\mathrm{Da} \mathrm{Paz}$ et al. (2008) also considered that errors in the calculated river lengths were due to the inability of a low resolution DEM to delineate meanders cor- 
rectly in higher order segments. Our results also showed that lower resolution DEMs generated slightly higher mean upstream slopes, especially for $\mathrm{AH}$ and $\mathrm{HGH}$. This could be related to the fact that lower resolution DEMs yielded smaller mean segment lengths (i.e., channels with lower sinuosity). Clarke et al. (2008) and Davies et al. (2007) also found that segment slopes greatly depend on DEM resolution, as segment length tends to increase when DEM resolution become finer.

\section{Discrimination ability of TRN variables}

The wide variety of channel types and factors conditioning channel morphology greatly complicates the ability to discriminate between stream types (Montgomery \& Buffington, 1998; Wohl \& Merritt, 2005). Catchment size (Leopold et al., 1964), topography (Wohl \& Merritt, 2005; Flores et al., 2006), land cover and uses (Strayer et al., 2003; Allan, 2004), river network configuration and confluence effects (Benda et al., 2004; Benda et al., 2007) and adjustment to local factors (Montgomery \& Buffington, 1998) are often considered to be among the most important controlling factors of channel morphology. Channel bed slope is one of the variables that has been most commonly used to classify streams (e.g., Rosgen, 1994; Montgomery \& Buffington, 1997; Wohl \& Merritt, 2005). Flores et al. (2006) found that specific stream power, based on contributing area and local channel slope, was a reliable predictor to discriminate between four mountain channel-reach types. Other authors have also used stream segment slopes derived from DEMs to detect high-quality habitat for anadromous salmon (Lunetta et al., 1997; Burnett et al., 2003; Burnett et al., 2007). The results of our study showed that catchment area, segment slope, mean upstream slope and stream power were all important variables discriminating between the 3 channel groups.

Given the better results obtained with NS regarding spatial accuracy and network structure, we would expect that NS-TRN would exhibit greater discrimination ability between groups than other software packages. However, the dif- ferences in the discrimination rates between software packages were not important, except for the $90 \mathrm{~m}$ DEM, for which AH obtained an overall classification $18 \%$ higher than NS. These results show that DEM spatial resolution is important to discriminate group membership because it affects segment and mean upstream slope values derived from the TRNs, as has been shown previously. According to other authors (Wang \& Yin, 1998; Davies et al., 2007; da Paz et al., 2008), a DEM with a higher spatial resolution is capable of representing segment slope more accurately, so it may be more valuable in predicting stream habitat characteristics in combination with other variables at different spatial scales. It should be noted that our study and other investigations (Lunetta et al., 1997; Wohl \& Merritt, 2005; Flores et al., 2006) were conducted in steep mountain catchments, where segment slope may be one of the main variables controlling instream characteristics. Thus, it could be interesting to extend this study to rivers with lower and more homogeneous slopes, where other variables may exert greater influence.

In conclusion, we found that DEMs with higher spatial resolution improve the derivation of terrain characteristics, TRN spatial accuracy and structure and the ability of derived variables to discriminate between stream types. Nevertheless, some of our results did not support this conclusion, quite likely because river network extraction quality and DEM spatial resolution do not exhibit a simple relationship, and a large number of factors, such as local terrain characteristics, the process of DEM generation from raw data, the DEM information source and the drainage threshold definition produce complex results. The use of DEMs with higher spatial resolution is associated with increasing computational time, which should be evaluated depending on the aims of each study. However, the three software packages used to extract TRNs in this study did not present great differences in resource consumption, while NS generated more accurate results, especially when high resolution DEMs were available. 


\section{ACKNOWLEDGEMENTS}

The work described in this paper is part of a research project financed by the National Plan (2008-2011) for Research in Science \& Technology of the Spanish Government (Project CTM2009-07447). The authors appreciate the valuable suggestions of anonymous reviewers that greatly improvement the document.

\section{REFERENCES}

ALLAN, J. D. 2004. Landscapes and riverscapes: The influence of land use on stream ecosystems. Annual Review of Ecology Evolution and Systematics, 35: 257-284.

BENDA, L. \& T. DUNNE. 1997. Stochastic forcing of sediment supply to channel networks from landsliding and debris flow. Water Resources Research, 33(12): 2849-2863.

BENDA, L., D. MILLER, K. ANDRAS, P. BIGELOW, G. REEVES \& D. MICHAEL. 2007. NetMap: A New Tool in Support of Watershed Science and Resource Management. Forest Science, 53(2): 206-219.

BENDA, L., N. L. POFF, D. MILLER, T. DUNNE, G. REEVES, G. PESS \& M. POLLOCK. 2004. The Network Dynamics Hypothesis: How Channel Networks Structure Riverine Habitats. Bioscience, 54(5): 413-427.

BUFFAGNI, A., G. A. CROSA, D. M. HARPER \& J. L. KEMP. 2000. Using macroinvertebrate species assemblages to identify river channel habitat units: an application of the functional habitats concept to a large, unpolluted Italian river (River Ticino, northern Italy). Hydrobiologia, 435(1-3): 213225.

BURNETT, K., G. H. REEVES, D. MILLER, S. CLARKE, K. CHRISTIANSEN \& K. VANCEBORLAND. 2003. A first step toward broad-scale identification of freshwater protected areas for Pacific salmon and trout in Oregon, U.S.A. In: Aquatic protected areas: What works best and how de we know? Proceedings of the World Congress on Aquatic Protected Areas. J. P. Beumer, A. Grant \& D. C. Smith (eds.): 144-154. Australian Society for fish Biology, North Beach, WA, Australia.

BURNETT, K. M., G. H. REEVES, D. J. MILLER, S. CLARKE, K. VANCE-BORLAND \& K. CHRIS-
TIANSEN. 2007. Distribution of salmon-habitat potential relative to landscape characteristics and implications for conservation. Ecological Applications, 17(1): 66-80.

BURROUGH, P. A. \& R. MCDONELL. 1998. Principles of Geographical Information Systems., Oxford, University Press. 352 pp.

CLARKE, S. \& K. BURNETT. 2003. Comparison of digital elevation models for aquatic data development. Photogrammetric Engineering and Remote Sensing, 69(12): 1367-1375.

CLARKE, S. E., K. M. BURNETT \& D. J. MILLER. 2008. Modeling Streams and Hydrogeomorphic Attributes in Oregon From Digital and Field Data. Journal of the American Water Resources Association, 44(2): 459-477.

COLOMBO, R., R. V. VOGT, P. SOILlE, M. L. PARACCHINI \& A. DE JAGER. 2007. Deriving river networks and catchments at the European scale from medium resolution digital elevation data. Catena, 70(3): 296-305.

DA PAZ, A. R., W. COLLISCHONN, A. RISS \& C. A. B. MENDES. 2008. Errors in river lengths derived from raster digital elevation models. Computers \& Geosciences, 34(11): 1584-1596.

DAVIES, J. R., K. M. LAGUEUX, B. SANDERSON \& T. J. BEECHIE. 2007. Modeling stream channel characteristics from drainage-enforced DEMs in Puget Sound, Washington, USA. Journal of the American Water Resources Association, 43(2): 414-426.

DEATH, R. G. \& M. K. JOY. 2004. Invertebrate community structure in streams of the ManawatuWanganui region, New Zealand: the roles of catchment versus reach scale influences. Freshwater $B i$ ology, 49: 982-997.

EEDY, R. I. \& D. J. GIBERSON. 2007. Macroinvertebrate distribution in a reach of a north temperate eastern Canadian river: Relative importance of detritus, substrate and flow. Fundamental and Applied Limnology, 169(2): 101-114.

ESRI. 2009. ArcGIS 9.3.1 Spatial Analyst. Redlands, CA, USA.

FLORES, A. N., B. P. BLEDSOE, C. O. CUHACIYAN \& E. E. WOHL. 2006. Channel-reach morphology dependence on energy, scale, and hydroclimatic processes with implications for prediction using geospatial data. Water Resources Research, 42(6): 1-15. 
FOX, P. J. A., M. NAURA \& P. SCARLETT. 1998. An account of the derivation and testing of a standard field method, River Habitat Survey. Aquatic Conservation: Marine and Freshwater Ecosystems, 8: 455-475.

FRANKLIN, P., M. DUNBAR \& P. WHITEHEAD. 2008. Flow controls on lowland river macrophytes: A review. Science of The Total Environment, 400(1-3): 369-378.

FRISSELL, C. A., W. J. LISS, C. E. WARREN \& M. D. HURLEY. 1986. A Hierarchical Framework for Stream Habitat Classification - Viewing Streams in a Watershed Context. Environmental Management, 10(2): 199-214.

GARBRECHT, J. \& L. W. MARTZ. 1997. The assignment of drainage direction over flat surfaces in raster digital elevation models. Journal of Hydrology, 193(1-4): 204-213.

GOBIERNO DE CANTABRIA. 2005. Estudio de los Recursos Hídricos de los Ríos de la Vertiente Norte de Cantabria. Consejería de Medio Ambiente, Gobierno de Cantabria, Santander Spain. 214 pp.

HORN, B. P. K. 1981. Hill shading and reflectance map. Proceedings of IEEE, 69(1): 14-47

JANA, R., T. V. RESHMIDEVI, P. S. ARUN \& T. I. ELDHO. 2007. An enhanced technique in construction of the discrete drainage network from low-resolution spatial database. Computers \& Geoscience, 33(6): 717-727.

JENK, G. F. 1967. The Data Model Concept in Statistical Mapping. International Yearbook of Cartography, 7: 186-190.

JENSON, S. K. \& J. O. DOMINGUE. 1988. Extracting Topographic Structure from Digital Elevation Data for Geographic Information-System Analysis. Photogrammetric Engineering and Remote Sensing, 54(11): 1593-1600.

JONES, K. H. 1998. A comparison of algorithms used to compute hill slope as a property of the DEM. Computers \& Geosciences, 24(4): 315-323.

KIENZLE, S. 2004. The Effect of DEM Raster Resolution on First Order, Second Order and Compound Terrain Derivatives. Transactions in GIS, 8: 83-111.

LAMOROUX, N., H. CAPRA \& M. POUILLY. 1998. Predicting Habitat suitability for lotic fish: Linking statistical hydraulic models with multivariate habitat use models. Regulated River: Research \& Management, 14(1): 1-11.
LEOPOLD, L. B., M. G. WOLMAN \& J. P. MILLER. 1964. Fluvial process in Geomorphology. Freeman, W. H. \& Company. San Francisco. 552 pp.

LI, J. \& D. W. S. WONG. 2010. Effects of DEM sources on hydrologic applications. Computers, Environment and Urban Systems, 34: 251-261.

LIN, W. T., W. C. CHOU, C. Y. LIN, P. H. HUANG \& J. S. TSAI. 2006. Automated suitable drainage network extraction from digital elevation models in Taiwan's upstream watersheds. Hydrological Processes, 20: 389-206.

LUNETTA, R. S., B. L. COSENTINO, D. R. MONTGOMERY, E. M. BEAMER \& T. J. BEECHIE. 1997. GIS-based evaluation of salmon habitat in the Pacific Northwest. Photogrammetric Engineering and Remote Sensing, 63(10): 1219-1229.

MAIDMENT, D. 2002. ArcHydro. GIS for Water Resources, ESRI Press. Redlands, California.

MARTINEZ-CAPEL, F. \& D. GARCIA DE JALÓN. 1999. Desarrollo de curvas de preferencia de microhábitat para Leuciscus pyrenaicus y Barbus bocagei por buceo en el río Jarama (cuenca del Tajo). Limnetica, 17: 71-83.

MARTZ, L. W. \& J. GARBRECHT. 1998. The treatment of flat areas and depressions in automated drainage analysis of raster digital elevation models. Hydrological Processes, 12(6): 843-855.

MCMASTER, K. J. 2002. Effects of digital elevation model resolution on derived stream network positions. Water Resources Research, 38(4): 1-8.

MILLER, D. 2003. Programs for DEM Analysis. Earth System Institute. Seattle, WA. 38 pp.

MILLER, D. J. \& K. M. BURNETT. 2008. A probabilistic model of debris-flow delivery to stream channels, demonstrated for the Coast Range of Oregon, USA. Geomorphology, 94(1-2): 184-205.

MONTGOMERY, D. R. \& J. M. BUFFINGTON. 1993. Channel classification, prediction of channel response, and assessment of channel condition. Report TFW-H10-93-002. Washington State Department of Natural Resources, Olymplia. 84 pp.

MONTGOMERY, D. R. \& J. M. BUFFINGTON. 1997. Channel-reach morphology in mountain drainage basins. Geological Society of America Bulletin, 109(5): 596-611.

MONTGOMERY, D. R. \& J. M. BUFFINGTON. 1998. Channel processes, classifiaction and response. In: River Ecology and Management. R. J. Naiman, R. E. Bilby \& S. Kantor (eds.): 13-42. Springer-Verlag, New York, USA. 
MONTGOMERY, D. R., G. E. GRANT \& K. SULLIVAN. 1995. Watershed Analysis as a Framework for Implementing Ecosystem Management. Water Resources Bulletin, 31(3): 369-386.

NAURA, M. \& M. ROBINSON. 1998. Principles of using River Habitat Survey to predict the distribution of aquatic species: an example applied to the native white-clawed crayfish Austropotamobius pallipes. Aquatic Conservation: Marine and Freshwater Ecosystems, 8: 515-527.

NELSON, A., H. I. REUTER \& P. GESSLER. 2009. DEM production methods and sources. In: Geomorphometry: concepts, software, applications. T. Hengl \& H. I. Reuter (eds.): 65-86. Developements in Soil Science, Vol. 33. Elsevier, Amsterdam.

PARASIEWICZ, P. 2008. Applications of MESOHABSIM using fish community targets. River Research and Applications, 24: 434-438.

R DEVELOPMENT CORE TEAM. 2008. R: A languaje and environment for statistical computing., $\mathrm{R}$ Foundation for Statistical Computing. Viena, Austria. 2630 pp.

RAVEN, P. J., P. FOX, M. EVERARD, N. T. H. HOLMES \& F. H. DAWSON. 1997. River Habitat Survey: a new system for classifying rivers according to their habitat quality. In: Freshwater quality: Defining the indefinable? P. J. Boon \& D. L. Howell (eds.): 215-234. The Stationery Office, Edinburgh.

RIVAS-MARTÍNEZ, S., A. PENAS \& T. E. DÍAZ. 2004. Bioclimatic Map of Europe, Bioclimates. In: Cartographic Service. University of León, León, Spain.

ROSGEN, D. L. 1994. A Classification of Natural Rivers. Catena, 22(3): 169-199.

SPSSINC. 2009. SPSS statistics Version 18.0.0.

STATSOFT INC. 1994. Statistica for the Windows operating system. StatSoft, Inc., Tulsa, USA.

STRAGER, M. P., J. T. PETTY, J. M. STRAGER \& J. BARKER-FULTON. 2009. A spatially explicit framework for quantifying downstream hydrologic conditions. Journal of Environmental Management, 90(5): 1854-1861.

STRAHLER, A. N. 1957. Quantitative analysis of watershed geomorphology. Transactions of the American Geophysicists Union, 38: 913-920.

STRAYER, D. L., R. E. BEIGHLEY, L. C. THOMPSON, S. BROOKS, C. NILSSON, G. PINAY \& R. J. NAIMAN. 2003. Effects of land cover on stream ecosystems: Roles of empirical models and scaling issues. Ecosystems, 6(5): 407-423.

TARBOTON, D. G. 1997. A New Method for the Determination of Flow Directions and Upslope Areas in Grid Digital Elevation Models. Water Resour. Res., 33(2): 309-319.

TARBOTON, D. G., R. L. BRAS \& I. RODRIGUEZITURBE. 1991. On the Extraction of Channel Networks from Digital Elevation Data. Hydrological Processes, 5(1): 81-100.

TAROLLI, P., R. J. ARROWSMITH \& E. R. VIVONI. 2009. Understanding earth surface processes from remotely sensed digital terrain models. Geomorphology, 113(1-2): 1-3.

USACE. 2000. HEC-HMS hydrologic modelling system user's manual. Hydrologic Engineering Centre, Davis, USA. 178 pp.

VANCE-BORLAND, K., K. BURNETT \& S. CLARKE. 2009. Influence of mapping resolution on assessments of stream and streamside conditions: lessons from coastal Oregon, USA. Aquatic Conservation-Marine and Freshwater Ecosystems, 19(3): 252-263.

VAUGHAN, I. P., M. DIAMOND, A. M. GURNELL, K. A. HALL, A. JENKINS, N. J. MILNER, L. A. NAYLOR, D. A. SEAR, G. WOODWARD \& S. J. ORMEROD. 2009. Integrating ecology with hydromorphology: a priority for river science and management. Aquatic Conservation: Marine and Freshwater Ecosystems, 19(1): 113-125.

VOGT, J. V., R. COLOMBO \& F. BERTOLO. 2003. Deriving drainage networks and catchment boundaries: a new methodology combining digital elevation data and environmental characteristics. Geomorphology, 53(3-4): 281-298.

WANG, X. \& Z.-Y. YIN. 1998. A comparison of drainage networks derived from digital elevation models at two scales. Journal of Hydrology, 210(14): 221-241.

WOHL, E. \& D. MERRITT. 2005. Prediction of mountain stream morphology. Water Resources Research, 41, W08419: 1-10.

WU, S., J. LI \& G. H. HUANG. 2008. A study on DEM-derived primary topographic attributes for hydrologic applications: Sensitivity to elevation data resolution. Applied Geography, 28(3): 210-223.

ZHANG, X. Y., N. A. DRAKE, J. WAINWRIGHT \& M. MULLIGAN. 1999. Comparison of slope estimates from low resolution DEMs: Scaling issues and a fractal method for their solution. Earth Surface Processes and Landforms, 24(9): 763-779. 
ZHOU, Q. \& X. LIU. 2004. Analysis of errors of derived slope and aspect related to DEM data properties. Computers \& Geosciences, 30(4): 369-378.
ZHU, Q., Y. TIAN \& J. ZHAO. 2006. An efficient depression processing algorithm for hydrologic analysis. Computers \& Geosciences, 32(5): 615-623. 
